\title{
Antioxidant activities of Barringtonia racemosa leaves
}

\author{
Nurul Syafizan, R. and *Rabeta, M.S. \\ Food Technology Division, School of Industrial Technology, Universiti Sains Malaysia, 11800 Minden, \\ Penang, Malaysia
}

\begin{abstract}
Article history:
Received: 23 November 2017

Received in revised form: 20

December 2017

Accepted: 21 December 2017

Available Online: 22

December 2017

Keywords:

Proximate analysis,

Total phenolic content,

Total flavonoid content,

Total condensed tannin,

Antioxidant activities
\end{abstract}

DOI:

https://doi.org/10.26656/fr.2017.2(2).285

\begin{abstract}
Proximate analysis of Barringtonia racemosa (putat) leaves was carried out and total phenolic content (TPC) was measured using total phenolic assay, also known as the Folin Ciocalteu (FC) assay. Antioxidant activities of the methanolic and aqueous extracts were evaluated by ferric reducing antioxidant power (FRAP) assay; the free radical scavenging capacity was determined by 1,1-diphenyl-1-picrylhydrazyl radical scavenging capacity (DPPH) assay. Proximate analysis showed that the leaves contained $70.52 \%$ moisture, $0.96 \%$ ash, $2.54 \%$ protein, $0.26 \%$ fat, $1.38 \%$ crude fiber, and $25.71 \%$ carbohydrates. The TPC amount exhibited by the methanolic extract was $1585.20 \pm 25.54 \mathrm{mg}$ GAE/100 g sample, which was higher compared with the aqueous plant extract with $1314.12 \pm 66.19$ mg GAE/100 $g(p<0.05)$. Significant $(p<0.05)$ difference in terms of the flavonoid content was observed between the extracts obtained by methanolic and aqueous extraction. Total condensed tannin content showed significant $(\mathrm{p}<0.05)$ difference between the methanolic and the aqueous extracts, which were $33.11 \pm 0.61 \mathrm{mg} C E / 100 \mathrm{~g}$ and $13.38 \pm 0.87 \mathrm{mg}$ $\mathrm{CE} / 100 \mathrm{~g}$, respectively. Methanolic extract of Barringtonia racemosa leaves showed a higher DPPH scavenging activity than the aqueous extract. FRAP value for the methanolic extract of the sample was higher than the aqueous extract, with a significant difference $(p<0.05)$. Results of this study will provide a platform for the future paradigm of these potential natural sources of antioxidants in food and nutraceutical applications.
\end{abstract}

\section{Introduction}

Antioxidants are used in foods to prevent food oxidation and prolong shelf life, as well as a dietary supplement to prevent harmful oxidation reactions occurring in the physiological systems of the human body (Venkatesh and Sood, 2011). The natural sources of antioxidants obtained from the human diet include cereals, vegetables, fruits, oilseeds, legumes, cocoa products, beverages, herbs and spices (Pokorny, 2007). Among the types of antioxidants used widely today are enzymes, proteins, vitamins (A, C, E), carotenoids, polyphenols, trace elements and small molecules, such as glutathione (Tabart et al., 2007). The antioxidants are important to overcome the overproduction reactive oxygen species (ROS) in our body (Wong et al., 2009).

Several studies have been conducted to discover new antioxidant sources with cheaper cost and consistent supply, which will be used in the food industry (Velentao et al., 2002). Natural antioxidants are presumed to be safer apart having nutritional and therapeutic values ( $\mathrm{Li}$ et al., 2009).
Barringtonia racemosa (Lecythidaceae family) has long been used in traditional Asian medicine. South-East Asians consume the shoots or young leaves of this plant, either fresh or boiled (Dhiya et al., 2007). According to Kong et al. (2012), the pounded roots and barks of Barringtonia racemosa is believed to reduce itchiness and chicken pox. Besides that, the leaves and barks of Barringtonia racemosa can be used as an antidote to snake bites, rat-poisoning and on boils (Nurul et al., 2008). By referring to Behbahani et al. (2007), the fruits of Barringtonia racemosa can be used to treat a cough, asthma, and diarrhea. Due to the various usage of Barringtonia racemosa in our folkloric medicine, it is suggested that it has an analgesic effect (Deraniyagala et al., 2003).

This study was performed to accomplish the following objectives: analyze and determine the proximate composition, the total phenolic, flavonoid, and condensed tannin contents; and the antioxidant properties of Barringtonia racemosa leaves. We used methanol and aqueous as solvents extraction of antioxidant activities 
due to the presence of various chemical groups such as total phenolic, flavonoid and tannins with different chemical characteristics and polarities.

\section{Materials and methods}

\subsection{Plant material and sample preparation}

Samples were collected from November 2012 to April 2013 in Kulim, Kedah, Malaysia. B. racemosa leaves were identified by Dr. Rahmad Zakaria. Voucher specimen number 11399 was deposited in the herbarium laboratory of the School of Biological Sciences, Universiti Sains Malaysia. Exactly $3 \mathrm{~kg}$ of the fresh leaves were separated from the stems and washed under running tap water to remove dirt and particulates.

\subsection{Sample extraction}

Sample extraction was conducted based on the procedure of Sulaiman et al. (2011). Approximately $10 \mathrm{~g}$ of fresh samples were washed with distilled water and dried using blotting paper (Whatman 3MM) to remove the remaining water on the leaf surface. The leaves were ground to obtain a fine paste and then soaked in $100 \mathrm{~mL}$ of solvent (distilled water or $70 \%$ ethanol) for $1 \mathrm{~h}$ at room temperature. The obtained extract was filtered using clean muslin cloth and centrifuged (Hittech EBA 20 Centrifuge) at $61,000 \times g$ for $15 \mathrm{~min}$. The fresh extracts were stored at $4^{\circ} \mathrm{C}$ in the dark for further analysis.

\subsection{Proximate analysis}

Proximate analysis of the samples, which include moisture content, ash, crude protein, fat, and crude fiber, was determined according to the methods set forth by the Association of Analytical Chemist (AOAC), 2000. Percentage of carbohydrate content was determined by the following formula: $\%$ Carbohydrate $=100-(\%$ ash $+\%$ fat $+\%$ protein $+\%$ fiber content)

\subsection{Total phenolic content}

Folin Ciocalteu (FC) assay was used to find out the total phenolic content (TPC) of the sample based on the procedure of Dhiya et al. (2011). Approximately $0.5 \mathrm{~mL}$ of the leaf extract containing different concentrations of gallic acid was mixed with $2.5 \mathrm{~mL}$ of diluted $(1: 10)$ Folin-Ciocalteu reagent and $2 \mathrm{~mL}$ of $7.5 \% \mathrm{NA}_{2} \mathrm{CO}_{3}$. The mixture was incubated for $90 \mathrm{~min}$ at room temperature. The absorbance of the mixture was measured using UVvis spectrophotometer at $765 \mathrm{~nm}$. Gallic acid solutions with known concentrations $(0,20,40,60,80$, and $100 \mathrm{mg} / \mathrm{L}$ ) were prepared to create a standard curve.

\subsection{Total flavonoid content}

Calorimetric assay was used to find out the total flavonoid content of the sample based on the procedure of Nurul et al. (2008). Approximately $1 \mathrm{~mL}$ of the sample aliquot was added to $4 \mathrm{~mL}$ of distilled water $\left(\mathrm{dH}_{2} \mathrm{O}\right)$. Approximately $0.3 \mathrm{~mL}$ of $5 \%(\mathrm{w} / \mathrm{v})$ sodium nitrite and $0.3 \mathrm{~mL}$ of $10 \%(\mathrm{w} / \mathrm{v})$ aluminium chloride were sequentially added to the mixture after $5 \mathrm{~min}$. Two $\mathrm{mL}$ of $1 \mathrm{M}$ sodium hydroxide solution was added on the $6^{\text {th }} \mathrm{min}$; the total volume was increased to $10 \mathrm{~mL}$ by adding distilled water. The mixture was then shaken energetically by vortex. The absorbance of spectrophotometer was measured at $510 \mathrm{~nm}$. A standard curve was plotted using catechin solution at various concentrations $(0,20,40,60,80,100$, and $120 \mathrm{mg} / \mathrm{L})$.

\subsection{Condensed tannin content}

Vanillin assay was used to determine the condensed tannin content of the sample, based on the procedure of Wijekoon et al. (2010). About $0.5 \mathrm{~mL}$ of the leaf extract of $B$. racemosa was added to $3 \mathrm{~mL}$ of vanillin reagent $(4 \% \mathrm{w} / \mathrm{v}$ vanillin in methanol) and heterogeneous. About $1.5 \mathrm{~mL}$ of concentrated hydrochloric acid was added and the mixture was then vortexed. Afterward, the mixture was covered with aluminium foil for $15 \mathrm{~min}$ at $25^{\circ} \mathrm{C}$ and the absorbance was measured using UV-vis spectrophotometer at $500 \mathrm{~nm}$. A standard curve was plotted using catechin solution at various concentrations $(0,20,40,60,80,100$, and $120 \mathrm{mg} / \mathrm{L})$. The content of condensed tannins in the leave of $B$. racemosa was measured as mg catechin equivalent (CE) per gram (dry weight basis) of the fresh sample.

\subsection{1,1-diphenyl-2-picrylhydrazyl (DPPH) free radical scavenging assay}

Determination of scavenging activity was based on the procedure of Subhasree et al. (2009). Methanolic DPPH was freshly prepared by mixing DPPH solution with methanol at a concentration of $100 \mu \mathrm{mol} / \mathrm{L}$. Approximately $1 \mathrm{~mL}$ of the sample extract was mixed with $6 \mathrm{~mL}$ of DPPH solution. The control was done by adding $1 \mathrm{~mL}$ of methanol to $6 \mathrm{~mL}$ of DPPH solution into the test tubes with the lids containing the samples were covered with aluminum foil. Then, the mixture was then shaken energetically and kept without light for $30 \mathrm{~min}$. The absorbance was measured against the blank at $517 \mathrm{~nm}$ using UV-vis spectrophotometer (Shimadzu UVVisible Recording Spectrophotometer Model UV-160A).

\subsection{Ferric-reducing antioxidant power (FRAP) assay}

FRAP assay was performed according to the procedure of Kong et al. (2012). The FRAP reagent was done by adding acetate buffer, 2,4,6-tripyridyl-s-triazine 
(TPFZ) solution to $40 \mathrm{mM} \mathrm{HCl}$ and $20 \mathrm{mM}$ iron (III) chloride at a volume ratio 10:1:1 and then warmed in the water bath at $37^{\circ} \mathrm{C}$ prior to analysis. Diluted sample extract $(200 \mu \mathrm{L})$ was mixed with $3 \mathrm{~mL}$ of FRAP reagent. The blank sample was prepared by mixing the FRAP reagent with distilled water. The mixtures were then incubated in the water bath $\left(37^{\circ} \mathrm{C}\right)$ for $30 \mathrm{~min}$. Sample absorbance was determined against the blank using UVVis spectrophotometer at $595 \mathrm{~nm}$ after $30 \mathrm{~min}$. Solutions of $\mathrm{FeSO}_{4} .7 \mathrm{H}_{2} \mathrm{O}$ with known concentrations $(0,200,400$, 600 , and $800 \mu \mathrm{M})$ were used to prepare a standard curve. Values obtained were expressed as $\mathrm{mmol} \mathrm{Fe}^{2 \pm}$ per gram (dry weight basis) of fresh sample.

\subsection{Statistical analysis}

Results obtained were presented as mean values at \pm SD. Duncan's test at $\mathrm{p}<0.05$, analysis of variance (ANOVA) was done to determine the significant differences for multiple comparisons. SPSS version 20.0 was used to conduct all statistical analysis.

\section{Results and Discussion}

\subsection{Proximate analysis}

The moisture content of the fresh sample, which averaged at $70.52 \pm 0.25 \%$, was quite high. High moisture content in most fruits and vegetables provides a conducive environment for growth and multiplication of microorganisms (Hassan et al., 2007). In addition, the sample is highly perishable, and should thus be stored properly for longer shelf life (Adeleke and Abiodun, 2015). Excessive moisture can lead to a higher tendency for spoilage and rotten products in the agricultural and food industries (Austin et al., 2013).

Removal of water and other organic matter present in foods by heating produces an inorganic residue known as ash (Kok, 2012). Ash content is an index of the total mineral element (Aliero and Abdullah, 2009). Ash content of the fresh Barringtonia racemosa leaves was $0.96 \pm 0.06 \%$, which indicates low mineral content in the plant. Nwachukwu and Ukoha (2007) reported that mineral content is directly proportional to drying. The drier the leaves are, the higher is the ash content. Ash content is directly proportional to drying; hence, the value of ash content in the fresh sample is low because of less surface area and low reaction rate.

Nitrogen content determination in food samples is based on its conversion into simple nitrogen derivatives, which remains to be the official method for determining the overall protein content in many countries, especially for foods where separation of the specific proteins from other components in the sample is not required unless the food contains appreciable amounts of non-protein nitrogen-containing material (Bonomi, 2005). Table 1 showed that the protein content of the fresh matured leaves of Barringtonia racemosa ranged from $2.51 \%$ to $2.57 \%$ and the average protein content was $2.54 \%$. This result is consistent with results of a previous study on protein content in the matured leaves of Barringtonia racemosa done by Kok (2012). Ratnayake and Galli (2009) reported that fats and oils consist of a large number of organic compounds including fatty acids, monoacylglycerols, diacylglycerols, triacylglycerols, phospholipids, eicosanoids, resolvins, docosanoids, sterols, sterol esters, carotenoids, vitamins A and E, fatty alcohols, hydrocarbons, and wax esters. The benefits and potential risks of fat consumption should now be considered as key nutrients that affect early growth and development, as well as nutrition-related chronic diseases later in life (Burlingamea et al., 2009). The fat content of the fresh sample was $0.26 \pm 0.01 \%$.

Crude fiber measures the content of cellulose, hemicellulose, and lignin in foods (Ogunlakin et al., 2012). The presence of crude fiber in the intestinal tract aids in the proper peristaltic action of this body part (Kok, 2012). Crude fiber present in fresh B. racemosa leaves was in the range of $1.35 \%$ to $1.41 \%$, with an average of $1.38 \%$. Carbohydrate content of the leaves was quite low at $25.71 \pm 0.41 \%$ because of the presence of high amount of water in the leaves. Carbohydrates are ideal sources of energy for the body.

Table 1. Proximate composition of the matured leaves of Barringtonia racemosa

\begin{tabular}{cc}
\hline Proximate Analysis & $\mathbf{( \% )}$ \\
\hline Moisture & $70.52 \pm 0.25$ \\
Ash & $0.96 \pm 0.06$ \\
Protein & $2.54 \pm 0.03$ \\
Fat & $0.26 \pm 0.01$ \\
Crude Fiber & $1.38 \pm 0.03$ \\
Carbohydrate & $25.71 \pm 0.41$ \\
\hline
\end{tabular}

Values are expressed as mean \pm standard deviation $(n=3)$.

\subsection{Total phenolic content}

Phenolic compounds, which are known to have free radical scavenging properties, have shown antiinflammatory activity and medicinal and physiological functions in animals and plants (Blasa et al., 2010). TFC assay is one of the oldest methods designed to determine the total content of phenolics (total phenols) (Roginsky and Lissi, 2005). This assay involves the transfer of electrons in alkaline medium from phenolic compounds and other reducing species to molybdenum, producing blue complexes that can be detected by spectrophotometer at $750 \mathrm{~nm}$ to $765 \mathrm{~nm}$ (Magalhaes, 2008). 
The amount of TPC in the methanolic extract was $1585.20 \pm 25.54 \mathrm{mg}$ GAE/100 g sample, which was higher compared with the TPC obtained from the aqueous plant extract at $1314.12 \pm 66.19 \mathrm{mg} \mathrm{GAE} / 100 \mathrm{~g}$ $(p<0.05)$ (Table 2). A significant difference in the TPC concentration was observed between the two extracts because the phenolic compounds in plants are more soluble in methanol (Roginsky and Lissi, 2005). Thus, methanol is a more efficient solvent for extracting phenolic compounds in fresh matrices of Barringtonia racemosa leaves. The acidified organic solvent destroys the plant's cell membranes and simultaneously dissolves the anthocyanins, resulting to a higher amount of TPC.

Table 2. Total antioxidant capacity (DPPH and FRAP) and antioxidant activity of phenolics, flavonoids and condensed tannins of Barringtonia racemosa leaves

\begin{tabular}{lcc}
\hline \multirow{1}{*}{ Analysis } & \multicolumn{2}{c}{ Extraction } \\
\cline { 2 - 3 } $\begin{array}{l}\text { Total Phenolic Content } \\
\text { (mg GAE/100g }\end{array}$ & $1585.20 \pm 25.54^{\mathrm{e}}$ & $1314.12 \pm 66.19^{\mathrm{d}}$ \\
$\begin{array}{l}\text { sample) } \\
\text { Total Flavonoid }\end{array}$ & & \\
$\begin{array}{l}\text { Content } \\
\text { (mg CE } / 100 \mathrm{~g} \text { of }\end{array}$ & $239.35 \pm 2.02^{\mathrm{c}}$ & $170.96 \pm 1.28^{\mathrm{c}}$ \\
$\begin{array}{l}\text { sample) } \\
\text { Total Condensed }\end{array}$ & & \\
$\begin{array}{l}\text { Tannins } \\
\text { (mg CE } / 100 \mathrm{~g} \text { of }\end{array}$ & $33.11 \pm 0.61^{\mathrm{a}}$ & $13.38 \pm 0.87^{\mathrm{a}}$ \\
sample) & & \\
$\begin{array}{l}\text { DPPH (\% inhibition) } \\
\text { FRAP }(\mu \mathrm{M} \text { Fe (11)/g of } \\
\text { sample) }\end{array}$ & $85.34 \pm 0.84^{\mathrm{b}}$ & $79.10 \pm 1.17^{\mathrm{b}}$ \\
\hline
\end{tabular}

Means with different superscript in any column are significantly different at $p<0.05$, same superscript in any column indicates $\mathrm{p}>0.05$ with no significant difference, according to Duncan's Multiple-Range Test $(\mathrm{n}=3)$

The extracting solvents with different polarities influence the solubility of the chemical constituents in the sample and its extraction yield (Sulaiman et al., 2011). Alothman et al. (2009) reported that the recovery of phenolic compounds is dependent on the solvent used and the polarity of the sample. Moreover, solvent polarity has an important role in increasing phenolic solubility (Naczk and Shahidi, 2006). Higher phenol and flavonoid content in methanolic extracts account for better antioxidant activity results compared with aqueous extracts.

\subsection{Total flavonoid content}

Flavonoids are one of the most common subcategories of polyphenols, which are found naturally in foods (Venkatesh and Sood, 2011). Flavonoid is one of the bioactive compounds that can scavenge free radicals. Flavonoids have an important role in the defense-system mechanism of plants (Kok, 2012). Environmental conditions, such as air pollution and UV radiation, trigger the production of flavonoids (Dixon and Paiva, 1995). Flavonoids also act as a phytoalexin, which is an antimicrobial compound, in response to the presence of microorganisms (Maimoona et al., 2011). Flavonoid content was $239.35 \pm 2.02 \mathrm{mg} \mathrm{CE} / 100 \mathrm{~g}$ for the methanolic extract and $170.96 \pm 1.28 \mathrm{mg} \mathrm{CE} / 100 \mathrm{~g}$ for the aqueous extract $(\mathrm{p}<0.05)$. According to Sulaiman et al. (2011), flavonoids have low distribution and composition in the plants compared with the overall phenolics.

\subsection{Condensed tannin content}

The word 'tannin' refers to a heterogeneous group of polymeric phenolic compounds, and was originally used to describe plant extracts used to tan animal leather (Haslam, 1998). Tannins are polyphenols that occur in vascular plants and exist in two types; the condensed and the hydrolysable tannins (Wei et al., 2010). Condensed tannins, which are also called proanthocyanidins, are the most important studied group of polyphenols abundant in the plant kingdom (Lamy et al., 2011).

Using catechin as the standard monomer of condensed tannins in the assay results in red-colored adducts formation (Hagerman, 2002). The total condensed tannin content in the methanolic extract was $33.11 \pm 0.61 \mathrm{mg} \mathrm{CE} / 100 \mathrm{~g}$ and $13.38 \pm 0.87 \mathrm{mg} \mathrm{CE} / 100 \mathrm{~g}$ in the aqueous extract $(\mathrm{p}<0.05)$. According to Wijekoon et al. (2011), an abundance of hydroxyl groups and the presence of benzene rings gave the hydrophobic character to tannins. This finding can be the reason why the methanolic extract provided a higher yield of tannins compared with the aqueous extract.

Given that no study has been conducted on $B$. racemosa leaves with condensed tannins previously, the results obtained the current study can be used a reference to other future studies on B. racemosa leaves. Several factors can contribute to the different concentrations of condensed tannins in plant tissues, such as plant species, plant part, plant maturity, soil fertility, and growing season (Hagerman, 2002).

\subsection{DPPH and FRAP assay}

The DPPH inhibition in methanolic extract was $85.34 \pm 0.84 \%$ and $79.10 \pm 1.17 \%$ in aqueous extract. The antioxidant effect on DPPH attributed to the hydrogendonating ability of the solvent according to Adedapo et al. (2009). Markowicz et al. (2007) reported that, in the presence of hydrogen or any electron donor, the absorption intensity is decreasing, and the radical solution is discolored according to the number of 
electrons captured. The methanolic extract exhibited higher antioxidant activity with no significant difference $(\mathrm{P}>0.05)$ than the aqueous extract. According to Chan et al. (2009), methanol has been recommended for the extraction of phenolic compounds and antioxidants in fresh plant tissues because of its ability to inhibit polyphenol oxidase, which can alter antioxidant activity. High methanol extraction efficiency has been reported in the young leaves of Camelia sinensis (Chan et al., 2007).

The reducing ability of the extracts was $291.95 \pm 3.34 \mu \mathrm{M} \mathrm{Fe}(\mathrm{II}) / \mathrm{g}$ in the methanolic extract and $109.84 \pm 2.56 \mu \mathrm{M} \mathrm{Fe}(\mathrm{II}) / \mathrm{g}$ in the aqueous extract. FRAP values for the methanolic extracts were higher than the aqueous extract. The significant difference $(\mathrm{P}<0.05)$ observed between these two extracts is probably due to the solvent polarity towards the compounds in the leaves. According to Adedapo et al. (2009), increase in antioxidant activity is proportional to the polyphenol content. the active compound in $\mathrm{B}$. racemose leave was lycopene, an antioxidant (Behbahani et al., 2007).

\section{Conclusion}

This study showed that $B$. racemosa (L.) leaves have high antioxidant activity. Methanol was found to be suitable extraction solvent, showed significantly higher yield in DPPH, FRAP, total phenolic, and total flavonoid contents than aqueous extraction. Further studies should be carried out to establish the application and practicability of incorporating $B$. racemosa (L.) powder in any healthy processed products such as fiber powder booster, breakfast cereals, energy/fruit bar, and capsulated daily supplements.

\section{Conflict of Interest}

We declare that we have no conflict of interest.

\section{Acknowledgements}

School of Industrial Technology and Universiti Sains Malaysia Short Term Grant (304/PTEKIND/6310065) and (304/PTEKIND/6312124) contributed to the funding of this research.

\section{References}

Adedapo, A.A., Jimoh, F.O., Afolayan, A.J. and Masika, P.J. (2009). Antioxidant Properties of the Methanol Extracts of the Leaves and Stems of Celtis Africana. Records of Natural Product, 3(1), 23-31.

Adeleke, R.O. and Abiodun, O.A. (2010). Nutritional Composition of Breadnut Seed (Artocarpus camansi). African Journal of Agricultural Research,
5, 1273-1276.

Aliero, A.A. and Abdullahi, L. (2009). Effect of Drying on the Nutrient Composition of Vernonia amygdalina leaves. Journal of Phytology, 1(1), 2832.

Alothman, M., Bhat, R. and Karim, A.A. (2009). Antioxidant Capacity and Phenolic Content of Selected Tropical Fruits from Malaysia, Extracted with Different Solvents. Food Chemistry, 115, 785788. https://doi.org/10.1016/j.foodchem.2008.12.005

AOAC. (2000). Official methods of analysis of AOAC International. $17^{\text {th }}$ ed. Gaithersburg, MD, USA: Association of Official Analytical Chemists (AOAC) International.

Austin, J., Rodriguez, S., Pei-Fang, S. and Harris, M. (2013). Utilizing Microwaves for the Determination of Moisture Content Independent of Density. Powder Technology, 236, 17-23. https://doi.org/10.1016/ j.powtec.2012.06.039

Behbahani, M., Ali, A.M., Radzali, M. and Noorjahan, B.M. (2007). Anti-oxidant and Anti-Inflammatory Activities of Leaves of Barringtonia racemose. Journal of Medicinal Plants Research, 10, 095-102.

Blasa, M., Gennari, L., Angelino, D. and Ninfali, P. (2010). Fruit and Vegetable Antioxidants in Health, Bioactive Foods in Promoting Health: Fruits and Vegetables, p. 37 - 57. United States: Elsevier Inc. https://doi.org/10.1016/B978-0-12-374628-3.000037

Bonomi, F. (2005). Proteins/Foods, Encyclopedia of Analytical Science. $2^{\text {nd }}$ ed, p. 373-385. United States: Elsevier Academic Press

Burlingamea, B., Nishidab, C., Uauy, J. and Weisel, R. (2009). Fats and Fatty Acids in Human Nutrition: Introduction. Annals of Nutrition and Metabolism, 55, 5-7. https://doi.org/10.1159/000228993

Chan, E.W.C., Lim, Y.Y. and Chew, Y.L. (2007). Antioxidant Activity of Camellia sinensis Leaves and Tea from a Lowland Plantation in Malaysia. Food Chemistry, 102, 1214-1222. https:// doi.org/10.1016/j.foodchem.2006.07.009

Chan, E.W.C., Lim, Y.Y. and Omar, M. (2009). Antioxidant and Antibacterial Activity of Leaves of Etlingera species (Zingiberaceae) in Peninsular Malaysia. Food Chemistry, 104, 1586-1593. https:// doi.org/10.1016/j.foodchem.2007.03.023

Deraniyagala, S.A., Ratnasooriya, W.D. and Goonasekara, C.L. (2003). Antinociceptive Effect and Toxicological Study of the Aqueous Bark Extract of Barringtonia racemosa on rats. Journal of Ethnopharmacology, 86, 21-26. https:// doi.org/10.1016/S0378-8741(03)00015-1 
Dhiya, D.W., Hafsah, J. and Abdul, M.A. (2011). Total Phenolic Compounds and Antioxidant Properties in Different Stage of B.racemosa and B.spicata Leaf. 2011 International Conference on Biology, Environment and Chemistry, p. 24. Singapore: IACSIT Press.

Dixon, R.A. and Paiva, N.L. (1995). Stress-Induced Phenylpropanoid Metabolism. The Plant Cell, 7, 1085-1097. https://doi.org/10.1105/tpc.7.7.1085

Hagerman, A.E. (2002). Tannin Handbook. Retrieved from: http://www.users.miamioh.edu/hagermae/

Haslam, E. (1998). Practical polyphenols, From Structure to Molecular Recognition and Physiological Action; Cambridge University Press: Cambridge, UK.

Hassan, S.W., Umar, R.A., Maishanu, H.M., Matazu, I.K., Faruk, U.Z. and Sani, A.A. (2007). The Effect of Drying Method on the Nutrients and Nonnutrients Composition of Leaves of Gynandrophis gynandra (Capparaceae). Asian Journal of Biochemistry, 2, 349-353. https://doi.org/10.3923/ ajb.2007.349.353

Kok, Y.Q. (2012). Effects of Different Drying Methods on the Nutritional Values and Antioxidant Properties of Selected Local Fruits and Vegetables. Malaysia: Universiti Sains Malaysia, BSc. Thesis.

Kong, K.W., Sarni, M.J., Norhaniza, A., Amin, I. and Azlina A.A. (2012). Antioxidant Activities and Polyphenolics from the Shoots of Barringtonia racemosa (L.) Spreng in a Polar to A polar Medium System. Journal of Food Chemistry, 134, 324-332. https://doi.org/10.1016/j.foodchem.2012.02.150

Lamy, E., Rawel, H., Schweigert, F.J., Silva, F.C., Ferreira, A., Costa, A. R., Antunes, C., Almeida, A.M., Coelho, A.V. and Elvira, S.B. (2011). The Effect of Tannins on Mediterranean Ruminant Ingestive Behavior: The Role of the Oral Cavity. Molecules, 16, 2766-2784. https://doi.org/10.3390/ molecules 16042766

Li, X-Q., Ji, C., Sun, Y.Y., Yang, M-L. and Chu, X-G. (2009). Analysis of Synthetic Antioxidants and Preservatives in Edible Vegetable Oil by HPLC/TOF -MS. Food Chemistry, 113, 692-700. https:// doi.org/10.1016/j.foodchem.2008.07.072

Magalhaes, L.M., Segundo, M.A., Reis, S. and Lima, J.L.F.C. (2008). Methodological Aspects About In Vitro Evaluation of Antioxidant Properties. Analytica Chimica Acta, 613(1), 1-19. https:// doi.org/10.1016/j.aca.2008.02.047

Maimoona, A., Naeem, I., Saddiqe, Z., Ali, N., Ahmed, G. and Shah, I. (2011). Analysis of Total Flavonoids and Phenolic in Different Fractions of Bark and
Needle Extracts of Pinus roxburghii and Pinus wallichiana. Journal of Medicinal Plants Research, 5, 2724-2728.

Markowicz, B.D.H., Saldanha, L.A., Catharino, R.R., Sawaya, A.C.H.F., Cunha, I.B.S. and Carvalho, P.O. (2007). Phenolic Antioxidants Identified by ESI-MS from Yerba Maté (Ilex paraguariensis) and green tea (Camelia sinensis) extracts. Molecules, 12, 423-432. https://doi.org/10.3390/12030423

Naczk, M. and Shahidi, F. (2006). Phenolics in Cereals, Fruits and Vegetables: Occurrence, Extraction and Analysis. Journal of Pharmaceutical and Biomedical Analysis, 41, 1523-1542. https://doi.org/10.1016/ j.jpba.2006.04.002

Nurul, M.H., Radzali, M., Johari, R., Syahida, A. and Maziah, M. (2008). Antioxidant activities of different aerial parts of putat (Barringtonia racemosa L.). Malaysian Journal of Biochemistry and Molecular Biology, 6(2), 15-19.

Nwachukwu, N. and Ukoha, A.I. (2007). The Effect on the Micronutrient Composition of Five indigeneous Spices. Plant Product Research Journal, 11, 12-14.

Ogunlakin, G.O., Oke, M.O., Babarinde, G.O. and Olatunbosun, D.G. (2012). Effect of Drying Methods on Proximate Composition and Physico-chemical Properties of Cocoyam Flour. American Journal of Food Technology, 7(4), 245-250. https:// doi.org/10.3923/ajft.2012.245.250

Pokorny, J. (2007). Are Natural Antioxidants Better and Safer Than Synthetic Antioxidants? Journal of European Lipid Science and Technology, 109, 629642. https://doi.org/10.1002/ejlt.200700064

Ratnayake, W.M.N. and Galli, C. (2009). Fat and Fatty Acid Terminology, Methods of Analysis and Fat Digestion and Metabolism: A Background Review Paper. Annals of Nutrition and Metabolism, 55, 843. https://doi.org/10.1159/000228994

Roginsky, V. and Lissi, E.A. (2005). Review of Methods to Determine Chain-Breaking Antioxidant Activity in Food. Journal of Food Chemistry, 92, 235-254. https://doi.org/10.1016/j.foodchem.2004.08.004

Subhasree, B., Baskar, R., Keerthana, L.R., Susan, R.L. and Rajasekaran, P. (2009). Evaluation of Antioxidant Potential in Selected Green Leafy Vegetables. Food Chemistry, 115, 1213-1220. https://doi.org/10.1016/j.foodchem.2009.01.029

Sulaiman, S.F., Azliana, A.B.S., Kheng, L.O., Supriatno and Eng, M.S. (2011). Effect of Solvents in Extracting Polyphenols and Antioxidants of Selected Raw Vegetables. Journal of Food Composition and Analysis, 24, 506-515. https://doi.org/10.1016/ j.jfca.2011.01.020 
Tabart, J., Kevers, C., Sipel, A., Pincemail, J., Deraigne, J.O. and Dommes, J. (2007). Optimisation of Extraction of Phenolics and Antioxidants from Blackcurrant Leaves and Buds and of Stability During Storage. Journal of Food Chemistry, 105, 1268-1275. https://doi.org/10.1016/ j.foodchem.2007.03.005

Velentao, P., Fernandes, E., Carvalho, F., Andrade, P.B., Seabra, R.M. and Bastos, M.L. (2002). Antioxidative Properties of Cardoon (Cynara cardunculus L.) Infusion Against Superoxide Radical, Hydroxyl Radical, and Hypochlorous Acid. Journal of Agriculture Food Chemistry, 50, 4989-4993. https:// doi.org/10.1021/jf020225o

Venkatesh, R. and Sood, D. (2011). A Review of the Physiological Implications of Antioxidants in Food. USA: Worcester Polytechnic Institute, BSc. Thesis.

Wei, S.D., Zhou, H.C., Lin, Y.M., Liao, M.M. and Chai, W.M. (2010). Analysis of Condensed Tannins with Potent Antioxidant Activity from the Leaf, Stem Bark and Root Bark of Acacia confuse. Molecules, 15, 4369-4381. https://doi.org/10.3390/ molecules 15064369

Wijekoon, M.M.J.O., Bhat. R. and Karim, A.A. (2010). Effect of Extraction Solvents on the Phenolic Compounds and Antioxidant Activities of Bunga Kantan (Etlingera elatior Jack.) Inflorescence. Journal of Food Composition and Analysis, 24, 615619. https://doi.org/10.1016/j.jfca.2010.09.018

Wijekoon, M.M.J.O., Karim, A.A. and Bhat R. (2011). Evaluation of nutritional quality of torch ginger ((Etlingera elatior Jack.) Inflorescence. International Food Research Journal, 18(4), 14151420.

Wong, L.F., Lim, Y.Y. and Omar, M. (2009). Antioxidant and Antimicrobial Activities of Alpinia Species. Journal of Food Biochemistry, 33(6), 835851. https://doi.org/10.1111/j.1745-

4514.2009.00258.x 